\title{
Responses of Cytokinins, Antioxidant Enzymes, and Lipid Peroxidation in Shoots of Creeping Bentgrass to High Root-zone Temperatures
}

\author{
Zhaolong Wang1 \\ College of Agricultural and Biology Science, Shanghai Jiao Da University, Shanghai, China 201101 \\ John Pote ${ }^{2}$ and Bingru Huang ${ }^{3}$ \\ Department of Plant Biology and Plant Pathology, Rutgers University, New Brunswick, NJ 08901
}

\begin{abstract}
AdDitional index words. Agrostis stolonifera, heat stress, cytokinin, superoxide dismutase, catalase, malondialdehyde
Abstract. This study was designed to examine whether shoot injury induced by high root-zone temperature is associated with changes in shoot detoxifying metabolism and to determine the level and duration of high root-zone temperatures that would induce physiological changes in two cultivars of creeping bentgrass (Agrostis stolonifera var. palustris Huds) differing in heat tolerance. Plants of 'Penn A-4' (heat tolerant) and 'Putter' (heat susceptible) were grown in sand and exposed to root-zone temperatures of 20 (control), $21,22,23,25,27,31$, and $35^{\circ} \mathrm{C}$ in water baths while air temperature was maintained at $20^{\circ} \mathrm{C}$ in a growth chamber. Turf quality, leaf cytokinin content, and antioxidant enzyme activities declined at increased soil temperatures and the duration of treatment for both cultivars. A decline in turf quality occurred following 40 days of exposure to $35^{\circ} \mathrm{C}$ for 'Penn A-4' and 26 days of exposure to $31^{\circ} \mathrm{C}$ for 'Putter'. The root-zone temperature causing the decline of isopentenyl adenosine and zeatin cytokinins was $25^{\circ} \mathrm{C}$ at $37 \mathrm{~d}$ for 'Putter' and $27^{\circ} \mathrm{C}$ at $47 \mathrm{days}$ for 'Penn A-4'. The temperature causing the decline of superoxide dismutase and catalase activities was $25^{\circ} \mathrm{C}$ and $27^{\circ} \mathrm{C}$ at 33 days for 'Putter' and $27^{\circ} \mathrm{C}$ and $31^{\circ} \mathrm{C}$ at 43 days for Penn A-4, respectively. Malondialdehyde content increased at 27 ${ }^{\circ} \mathrm{C}$ for 'Putter' and $31{ }^{\circ} \mathrm{C}$ for 'Penn A-4' at 43 days of treatment. The decline in cytokinin content and antioxidant enzyme activity occurred at a lower soil temperature and earlier during the treatment than the decline in turf quality, possibly contributing to turf quality decline. The root-zone temperatures causing the decline in turf quality, cytokinin content, and oxidative damage were higher in the heat-tolerant cultivar than heat-susceptible cultivar.
\end{abstract}

The optimal temperatures for the growth of cool-season grasses are between 10 and $24^{\circ} \mathrm{C}$ (Beard, 1973). However, both air and soil temperatures often reach injuriously high levels during summer months, which strongly limits shoot and root growth and even survival of plants in many areas. Shoot injury in plants under environmental stresses has been associated with oxidative damage induced by the production of active oxygen species such as superoxide, hydrogen peroxide, hydroxyl radical, and singlet oxygen. These species are highly reactive and can damage many important cellular components such as lipids, proteins, and nucleic acids in living cells (Foyer et al., 1994; Smirnoff, 1993). Plants normally develop antioxidant defense systems that scavenge active oxygen species and protect cells against oxidative stress injury (Bowler et al., 1992; Zhang and Kirkham, 1996a, 1996b). Superoxide dismutase (SOD) and catalase (CAT) are two key antioxidant enzymes, and their combined effect averts cellular damage. Changes in the levels of antioxidants may be indicative of the levels of oxidative stress and stress resistance. When plants are subjected to stresses such as high or low temperatures, drought and salinity, the activities of antioxidant enzymes are inhibited, which can result in lipid peroxidation of cell membranes and cause leaf senescence (Bowler et al., 1992; Price and Hendry, 1989; Zhang and Kirkham, 1994).

Shoot growth inhibition and leaf senescence could be related to the inhibition of growth and hormone synthesis in roots at high root-zone temperatures (Udomprasert et al., 1995; Xu and Huang 2000a). Cytokinins are essential plant hormones involved in shoot meristem and leaf formation, cell division, chloroplast biogenesis,

Received for publication 28 Oct. 2002. Accepted for publication 9 Apr. 2003.

${ }^{1}$ Postdoctoral research associate.

${ }^{2}$ Graduate student.

${ }^{3}$ Associate professor and corresponding author; e-mail huang@aesop.rutgers.edu. and senescence (Binns, 1994). Cytokinins are produced mainly in roots and may regulate shoot responses to high root-zone temperatures. Cytokinin metabolism of roots is sensitive to heat stress. Two minutes of heat shock to the roots of tobacco (Nicotiana rustica L.) and bean (Phaseolus vulgaris L.) reduced cytokinin levels in both shoots and roots (Itai et al., 1973). Treatment with high air and soil temperatures $\left(45 / 45^{\circ} \mathrm{C}\right)$ for $5 \mathrm{~h}$ reduced the levels of zeatin riboside (ZR) and isopentenyl adenosine (iPA) in roots of both tepary bean (Phaseolus acutifolius A. Gray) and common bean (P. vulgaris) (Udomprasert et al., 1995). Heat stress also reduced ZR content in winter rape (Brassica napus L.) (Zhou and Leul, 1999). Leaves of transgenic plants with the isopentenyltransferase (ipt) gene inserted to enhance cytokinin synthesis maintained a green color under heat stress for a longer period than the non-transgenic control in Arabidopsis (A.thaliana) (Gan and Amasino, 1995). The positive effects of cytokinins on stress tolerance of plants are believed to be related to their protective effects from oxidative stress by preventing the formation of free radicals or by the regulation of antioxidant enzyme activities (Caers et al., 1985; Gunse and Eldtner, 1993; Leshem, 1984, 1988; Liu and Huang, 2002; Musgrave, 1994; Petit-Paly et al., 1999; Zhang and Schmidt, 2000).

Creeping bentgrass is a cool-season grass, widely used as turf on golf courses, and is sensitive to heat stress. Turf quality (color, uniformity, and density) often declines during summer months in many areas (Carrow, 1996). High root-zone temperature is more detrimental for plant growth than high air temperature, which can affect various physiological processes in shoots (Kuroyanagi and Paulsen, 1988; Huang and Xu, 2000; Paulsen, 1994; Ruter and Ingram, 1990, 1992; Udomprasert et al., 1995; Xu and Huang, $2000 \mathrm{a}, 2000 \mathrm{~b}, 2001)$. Reducing root-zone temperature from $35^{\circ} \mathrm{C}$ to $20^{\circ} \mathrm{C}$ significantly improved shoot growth and photosynthetic 
activities (Xu et al., 2002). However, physiological factors involved in root-temperature effects on shoot growth of cool-season grasses are not well understood. Specifically, it is unclear whether shoot injury of cool-season grasses induced by high root-zone temperatures is associated with changes in cytokinin status and oxidative damage of leaves. Previous studies examined cytokinins and antioxidant responses to heat stress in creeping bentgrass focused on effects of air temperature and worked only with one temperature $\left(35^{\circ} \mathrm{C}\right)$ (Liu and Huang, 2002). The critical level of high root-zone temperature that induces changes in cytokinin status and antioxidant enzyme activities in creeping bentgrass has not been determined.

The objectives of this study were to 1) investigate cytokinin content, the activities of antioxidant enzymes, and lipid peroxidation in shoots as affected by high root-zone temperatures for two creeping bentgrass cultivars differing in heat tolerance, 'Penn A-4' and 'Putter'; 'Penn A-4' was relatively more heat tolerant than 'Putter' based on summer performance, evaluated by visual turf quality and shoot density, on golf green conditions (USGA/GCSAA/NTEP, 1998); and 2) to determine the level and duration of high root-zone temperatures that induce a decline in turf quality, cytokinin production, enzyme antioxidant activities, and lipid peroxidation in shoots.

\section{Materials and Methods}

Plant materials and growth conditions. Two-year-old sod pieces of two creeping bentgrass cultivars, Putter and Penn A-4, were collected from field plots in Hort Farm II, Rutgers University, North Brunswick, N.J. Sods were washed with water to remove the soil and then transplanted into clear polyethylene bags ( 5 $\mathrm{cm}$ in diameter and $40 \mathrm{~cm}$ in length, with eight holes drilled at the bottom for drainage), which were filled with washed sand (particle size of 0.2 to $0.5 \mathrm{~mm}$ ) commonly used on golf greens. The polyethylene bags were placed in opaque polyvinylchloride (PVC) tubes of the same diameter and length, which were installed vertically in water baths with the lower open end exposed from the bottom of the water bath for drainage (Fig. 1) (Xu and Huang, 2001). The tubes were designed to enable plant growth to occur in well-drained sand in polyethylene tubes, while root-zone temperature was controlled at constant levels.

Plants were grown in a growth chamber at $20^{\circ} \mathrm{C}$ (day/night), $500 \mathrm{mmol} \cdot \mathrm{m}^{-2} \cdot \mathrm{s}^{-1}$ photoflux density, and a 14-h photoperiod for $60 \mathrm{~d}$ before the treatments were imposed. Before and during the Heater experiment, the turf was mowed daily at a 3-mm height with scissors, watered daily, and fertilized weekly with $50 \mathrm{~mL}$ of full strength Hoagland's nutrient solution (Hoagland and Arnon, 1950).

Shoots were maintained at $20{ }^{\circ} \mathrm{C}$ in the growth chamber. Root-zone temperatures were controlled at a constant day/night level of: 20 (control), 21, 22, 23, 25, 27, 31, and 35 ${ }^{\circ} \mathrm{C}$ by keeping the entire root-zone (40-cm-long sand column in a polyethylene bag) in different sub-compartments in a water bath while the turf canopy was kept approximately 1.0 $\mathrm{cm}$ above the water level in the water bath. The corresponding canopy temperatures were $20,19,19,20,20,21,22$, and $23^{\circ} \mathrm{C}$. Figure 1 shows the temperature-controlled water bath.
Details of the root-zone temperature-controlling system were also described in $\mathrm{Xu}$ and Huang (2001). A gradient of root-zone temperatures were created in separate subcompartments in a water bath. A heater was installed at one end of the water bath to heat water in this compartment to $38^{\circ} \mathrm{C}$. At another end of the water bath, cool water $\left(20^{\circ} \mathrm{C}\right)$ was added to maintain root-zone temperature at 20 ${ }^{\circ} \mathrm{C}$. Heating and cooling of water at the opposite ends of the water bath created different temperatures inside the water bath. Water levels were maintained at the top edge of the water bath and $0.5 \mathrm{~cm}$ below the top edge of PVC tubes during the experimental period. Root-zone temperatures were monitored daily using thermocouples placed into the root-zone at a depth of $10 \mathrm{~cm}$.

Temperature and cultivars were arranged in a split-plot randomized design with temperature as the main plot and cultivar as the subplot. Each root-zone temperature treatment was replicated four times in four different water baths in a walk-in growth chamber. Effects of root-zone temperature, cultivar, duration of treatment, and their interactions were determined by the analysis of variance according to the general linear model procedure of the Statistical Analysis System (SAS Institute, Cary, N.C.). Differences among treatments, cultivars, and durations of treatments were determined by the least significance difference (LSD) test at the 0.05 probability level.

Measurements. After treatments were initiated, turf quality was visually rated weekly based on color, density, and uniformity on a scale of 1 to 9 ( 1 is the worst where all plants were dead, and 9 is the best where all plants were healthy). Grasses rated at 6 or above were considered to have acceptable quality. Leaf samples were randomly collected from each treatment at various times of treatment and immediately put into liquid nitrogen and stored at $-80{ }^{\circ} \mathrm{C}$ for the assay of cytokinins and antioxidant enzymes. Cytokinin content and antioxidant activities were measured on different samples, because of the limited amount of leaf tissue for the analyses.

\begin{abstract}
Fig. 1. Diagram of a water bath controlling root-zone temperatures. The water bath was divided into nine sub-compartments that were maintained at nine distinct temperatures. Nine PVC tubes were installed in each compartment (controlled at a specific temperature level), which held nine polyethylene bags with plants. A heater was installed at one end of the water bath to heat water in this compartment to $38^{\circ} \mathrm{C}$. At another end of the water bath, cool water $\left(20^{\circ} \mathrm{C}\right)$ was added to maintain a root-zone temperature at $20^{\circ} \mathrm{C}$. Heating and cooling of water at the opposite ends of the water bath created a temperature gradient inside the water bath.
\end{abstract}

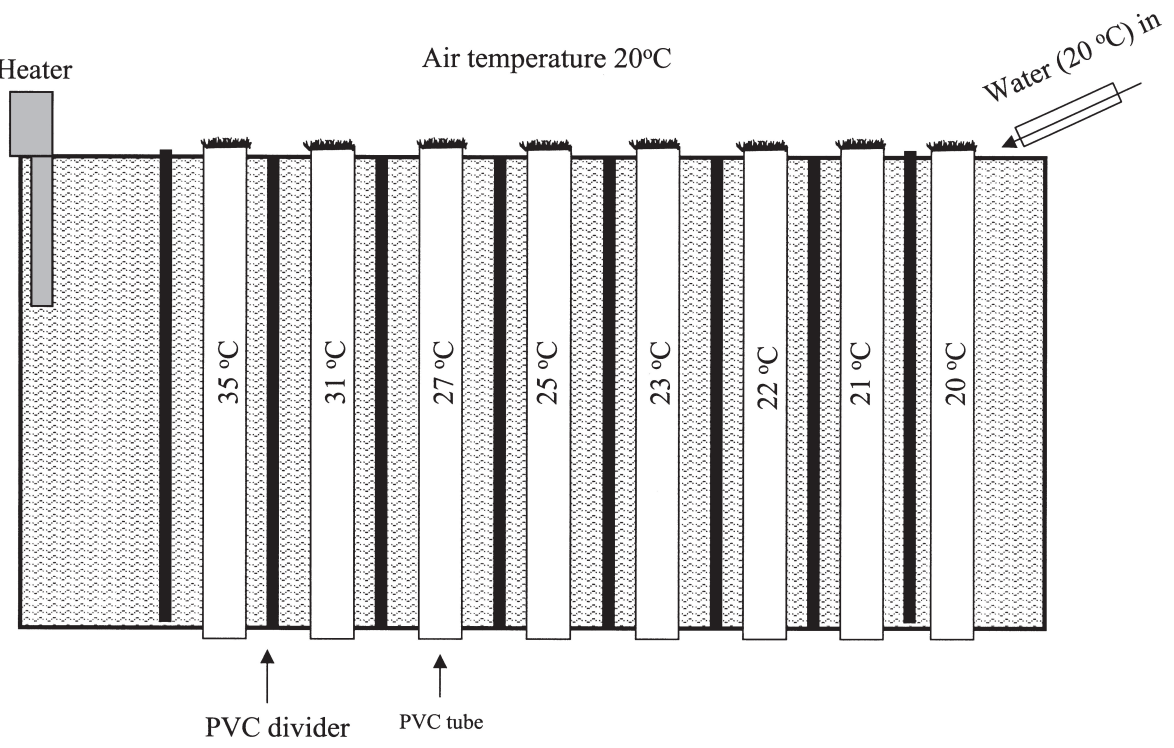


To extract antioxidant enzymes, $0.5 \mathrm{~g}$ frozen leaves were ground using a tissue grinder in $8 \mathrm{~mL}$ of $50 \mathrm{~mm}$ ice-cold phosphate buffer $(\mathrm{pH} 7.0)$ containing $1 \%(\mathrm{w} / \mathrm{v})$ polyvinypyrrolidone and 0.2 $\mathrm{g}$ of white quartz sand, which were placed in an ice bath. The homogenate was centrifuged at $15,000 \mathrm{~g}_{\mathrm{n}}$ for $20 \mathrm{~min}$ at $4^{\circ} \mathrm{C}$. The supernatant was used for the assay of enzyme activity and the level of lipid peroxidation.

The activity of SOD was determined by measuring its ability to inhibit the photoreduction of nitro blue tetrazolium (NBT) following the method of Giannopolitis and Ries (1977). The reaction solution $(3 \mathrm{~mL})$ contained $50 \mu \mathrm{M}$ NBT, $1.3 \mu \mathrm{M}$ riboflavin, $13 \mathrm{~mm}$ methionine, $75 \mathrm{~nm}$ EDTA, $50 \mathrm{~mm}$ phosphate buffer ( $\mathrm{pH} 7.8$ ), and $20 \mu \mathrm{L}$ enzyme extract, with non-enzyme solution as the control. Test tubes containing the reaction solution were irradiated under a light bank at $78 \mu \mathrm{mol} \cdot \mathrm{m}^{-2} \cdot \mathrm{s}^{-1}$ for $15 \mathrm{~min}$. The absorbance of the irradiated and nonirradiated solution at $560 \mathrm{~nm}$ was determined with a spectrophotometer (Spectronic Instruments, Inc., Rochester, N.Y.). One unit of SOD activity was defined as the amount of enzyme that would inhibit $50 \%$ of the NBT photoreduction.

Activity of CAT was measured using the method of Chance and Maehly (1955). The reaction solution ( $3 \mathrm{~mL}$ ) contained 50 mm phosphate buffer ( $\mathrm{pH} 7.0$ ), $15 \mathrm{~mm} \mathrm{H}_{2} \mathrm{O}_{2}$, and $0.1 \mathrm{~mL}$ enzyme extract. The reaction was initiated by adding the enzyme extract. Because of the linear decline of absorbance at $240 \mathrm{~nm}$ within the first $3 \mathrm{~min}$, changes in absorbance were read every min. One unit CAT activity was defined as an absorbance change of 0.01 units/min.

The lipid peroxidation level was determined in terms of malondialdehyde (MDA) content using the method described by Dhindsa et al. (1981). A 0.5-mL aliquot of extract was added to a tube containing $1 \mathrm{~mL} 20 \%(\mathrm{v} / \mathrm{v})$ trichloroacetic acid and $0.5(\mathrm{v} / \mathrm{v})$ thiobarbituric acid. The mixture was heated in a water bath at $95{ }^{\circ} \mathrm{C}$ for $30 \mathrm{~min}$. After cooling to room temperature and centrifuging at $10,000 \mathrm{~g}_{\mathrm{n}}$ for $10 \mathrm{~min}$, the absorbance of the supernatant was read at 532 and $600 \mathrm{~nm}$. The MDA content was calculated using the extinction coefficient of $155 \mathrm{~mm}^{\cdot} \mathrm{cm}^{-1}($ Heath and Packer, 1968).

The procedure for extraction and quantification of cytokinins in leaves followed the methods described by Setter et al. (2001) with modifications. Briefly, plant samples were extracted in $80 \%$ (by volume) methanol and then partially purified with reverse-phase chromatography on columns packed with $25 \mathrm{mg}$ of 40 - $\mu \mathrm{m}$-diameter $\mathrm{C}_{18}$-silica material (SPE-96, Supelco, Bellefonte, Pa.) (instead of self packed column in the original method). Samples were loaded in $100 \mu \mathrm{L}$ of solvent A (10 mM tri-ethylamine-acetate, $\mathrm{pH} 3.4)$. Hydrophilic contaminants were washed out with $200 \mu \mathrm{L}$ solvent B (85\% solvent A, $15 \%$ methanol, v/v) (instead of $20 \%$ methanol in the original method), and then the cytokinin-containing fraction was eluted with $200 \mu \mathrm{L}$ solvent C (65\% solvent A, 55\% methanol, v/v). Corresponding radioactive chemicals (Amersham Co., Arlington Heights, Ill.) were added to each sample to monitor the loss of radioactivity during the purification step. Recovery of each cytokinin compound averaged $>90 \%$ on the basis of analysis of radioactivity in non-cytokinin fractions.

An indirect competitive enzyme linked immunosorbant assay (ELISA) was used to quantify three kinds of cytokinins, trans-zeatin/zeatin riboside $(\mathrm{Z} /$ $\mathrm{ZR}$ ), dihydrozeatin/dihydrozeatin riboside (DHZ/
DHZR), and isopentenyl adenosine (iPA) as previously described by Setter et al. (2001). Partially purified cytokinin samples from $\mathrm{C}_{18}$ chromatography were dried in vacuo at $<24^{\circ} \mathrm{C}$, then were dissolved in $100 \mu \mathrm{L}$ of TBST (Tris-buffered saline, containing 1 $\mathrm{g} \cdot \mathrm{L}^{-1}$ Tween-20, $\mathrm{pH}$ 7.5). ELISA plates (Costar High Binding 3366, Corning, N.Y.) were coated overnight at $4{ }^{\circ} \mathrm{C}$ with 4 ng corresponding cytokinin-bovine serum albumin conjugate (MacDonald and Morris, 1985) in $200 \mu \mathrm{L}$ of $50 \mathrm{~mm} \mathrm{NaHCO}_{3}$ buffer, pH 9.6, containing $0.2 \mathrm{~g} \cdot \mathrm{L}^{-1} \mathrm{NaN}_{3}$. Plates were washed four times with TBST, and the following were added to each well: 10 to $30 \mu \mathrm{L}$ of sample, sufficient additional TBSA(Tris-buffered saline, containing $1 \mathrm{~g} \cdot \mathrm{kg}^{-1}$ bovine serum albumin, $\mathrm{pH} 7.5$ ) to bring to $100 \mu \mathrm{L}$, and $100 \mu \mathrm{L}$ of TBSA containing $1.4 \mu \mathrm{g}$ of monoclonal antibody. Monoclonal antibody for Z/ZR, DHZ/DHZR, and iPA were from clone $t$-ZR-J3-I-B3, cloneDHZR-J23-II-B1, clone iPA-J40-IV-C4, respectively (Eberle et al., 1986; currently available from Agdia Inc., Elkhart, Ind.). On each plate, the $\mathrm{C}$ and $\mathrm{F}$ rows were set for zeatin-riboside, dyhdrozeatin-riboside, or isopentenyladenosine (Sigma Chem. Co., St. Louis, Mo.) standards containing a 1:2 dilution series; 12 values from 20 to $0.01 \mathrm{pmol} /$ well served as a calibration curve in each assay. After incubation overnight at $4{ }^{\circ} \mathrm{C}$ and four washes by TBST, $200 \mu \mathrm{L}$ secondary antibody solution containing $10 \mathrm{~nL}$ of antimouse IgG-alkaline phosphatase conjugate (A-3562, Sigma Chemical Co., St. Louis, Mo.) in TBSA was added per well. After incubation overnight at $4{ }^{\circ} \mathrm{C}$ and four washes of TBST, $200 \mu \mathrm{L}$ of $p$-nitrophenyl phosphate (PNPP) solution (1 $\mathrm{g} \cdot \mathrm{L}^{-1}$ PNPP, $0.9 \mathrm{~m}$ diethanolamine, $3 \mathrm{~mm} \mathrm{MgCl}_{2}, \mathrm{pH}$ 9.8) was added for color development, and plates were incubated for about $1 \mathrm{~h}$ at $24^{\circ} \mathrm{C}$. The absorbance at $405 \mathrm{~nm}$ was read with a plate reader (model EL 800, Bio-Tek Instruments, Inc., Winooski, Vt.). Z/ZR, DHZ/DHZR, and iPA content were determined based on their calibration standards and a logit transformation of data (Wang et al., 2002). Assays were validated for absence

Fig. 2. Turf quality of 'Penn A-4' (heat tolerant) and 'Putter' (heat susceptible) creeping bentgrasses as affected by root-zone temperatures. Vertical bars at the top of the graphs indicate LSD values $(p=0.05)$ for cultivar comparisons within a given soil temperature treatment. Vertical bars on the right indicate LSD values $(p=0.05)$ for comparisons of different soil temperature treatments within a given cultivar: (A) $19 \mathrm{~d}$ after treatment; (B) $26 \mathrm{~d}$ after treatment; (C) 33 d after treatment; (D) $40 \mathrm{~d}$ after treatment.
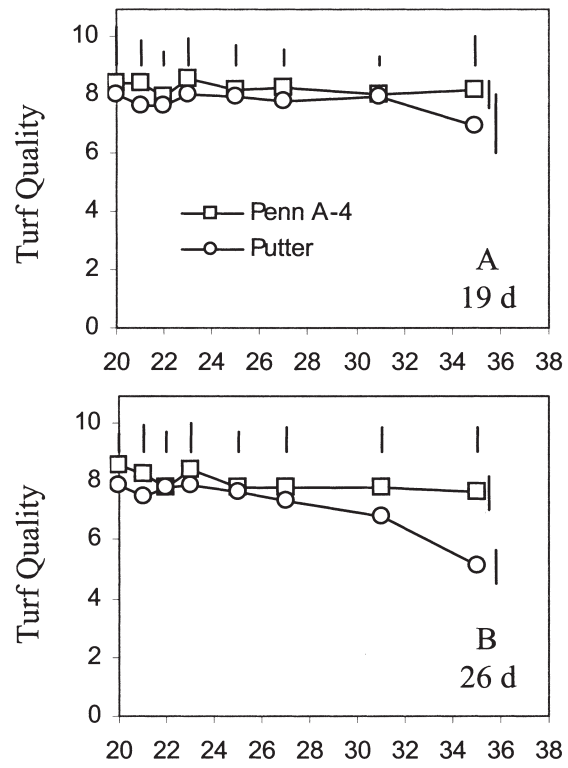

Root-zone temperature $\left({ }^{\circ} \mathrm{C}\right)$
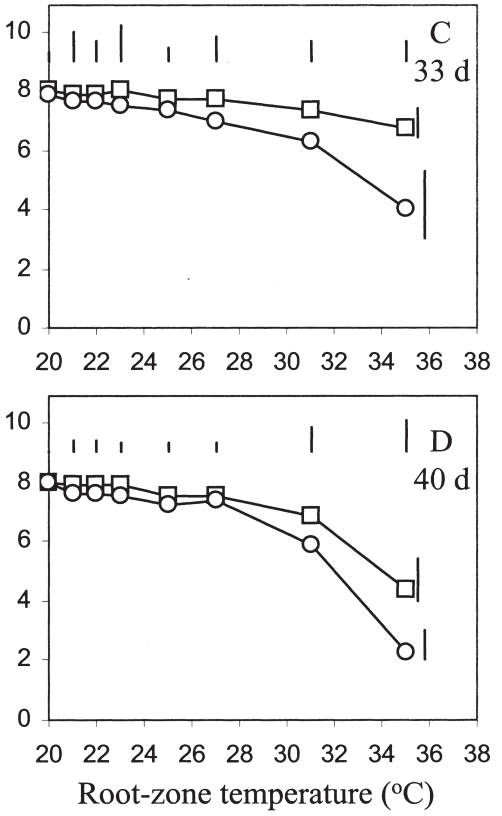

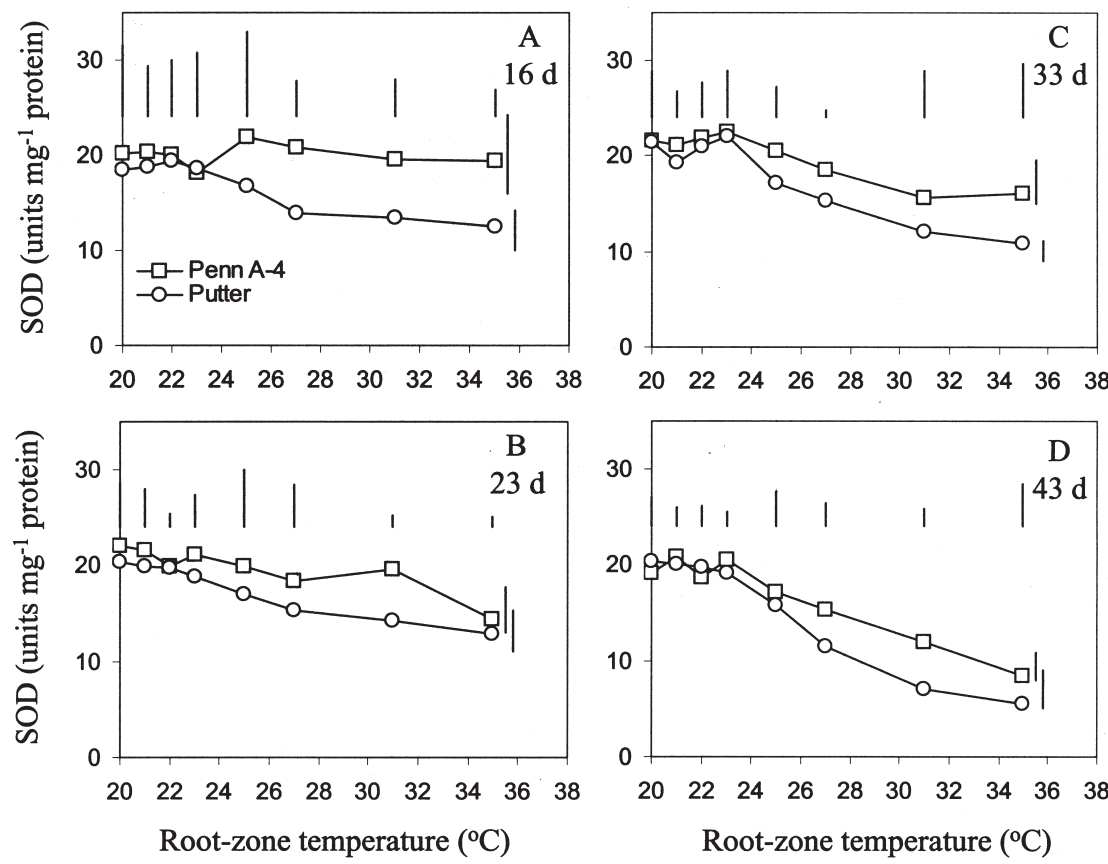

Fig. 3. Responses of shoot superoxide dismutase (SOD) activity of 'Penn A-4' (heat tolerant) and 'Putter' (heat susceptible) creeping bentgrasses to high soil temperatures. Vertical bars at the top of the graphs indicate LSD values $(p=0.05)$ for cultivar comparisons within a given soil temperature treatment. Vertical bars on the right indicate LSD values $(p=0.05)$ for comparisons of different soil temperature treatments within a given cultivar: (A) $16 \mathrm{~d}$ after treatment; (B) 23 $\mathrm{d}$ after treatment; (C) $33 \mathrm{~d}$ after treatment; (D) $43 \mathrm{~d}$ after treatment.

of interfering substances after chromatography as described by Pengelly (1986). Such tests indicated that a) when an equal quantity of hormone standard was added to various quantities of samples, prepared as described above, parallel curves were obtained, indicating a linearly additive response throughout the range, and b) when extracts were diluted, ELISA estimates were consistent with the dilution.

\section{Results}

TURF QUALITY. High root-zone temperatures had no effect on turf quality of either cultivar at $19 \mathrm{~d}$ of treatment (Fig. 2A). Turf quality of 'Putter' declined significantly at root-zone temperatures of $31^{\circ} \mathrm{C}$ at $26 \mathrm{~d}$, while turf quality of 'Penn A-4' declined under the $35^{\circ} \mathrm{C}$ temperature regime only at $40 \mathrm{~d}$ of treatment (Fig. 2B, D). Turf quality of 'Penn A-4' was significantly higher than 'Putter' at 31 and 35 ${ }^{\circ} \mathrm{C}$ at 26, 33, and $40 \mathrm{~d}$ of treatment.

Antioxidant EnZYMe activity. SOD activity of 'Putter' declined below the control level $\left(20^{\circ} \mathrm{C}\right)$ when root-zone temperature was maintained at $25^{\circ} \mathrm{C}$ or above for $33 \mathrm{~d}$ (Fig. $3 \mathrm{C})$; this decline occurred at $27^{\circ} \mathrm{C}$ at $16 \mathrm{~d}$ of treatment (Fig. 3A). SOD activity of 'Penn A-4' did not change under any temperature at $16 \mathrm{~d}$. The decline of SOD activity of 'Penn A-4' at $27{ }^{\circ} \mathrm{C}$ occurred only at $43 \mathrm{~d}$ of treatment (Fig. 3D).

The severity of the decline in SOD activity increased with temperature and the duration (Fig. 5D). of treatment for both cultivars. After $16 \mathrm{~d}$ of treatment (Fig. 3A) SOD activity for Penn A-4 was maintained at a higher level than 'Putter' at $27^{\circ} \mathrm{C}$. 'Penn A-4' had higher SOD activity than 'Putter' maintained at $31^{\circ} \mathrm{C}$ for $23 \mathrm{~d}$ (Fig. 3B), at $27^{\circ} \mathrm{C}$ for $33 \mathrm{~d}$ (Fig. 3C), and at 27 and $31^{\circ} \mathrm{C}$ for $43 \mathrm{~d}$ (Fig. $3 \mathrm{D})$. The cultivar difference diminished when rootzone temperatures were maintained at $35^{\circ} \mathrm{C}$.

CAT activity declined below the control level $\left(20^{\circ} \mathrm{C}\right)$ when root-zone temperature was maintained at $27^{\circ} \mathrm{C}$ and above for $23 \mathrm{~d}$ for 'Putter' and at $31^{\circ} \mathrm{C}$ and above at $23 \mathrm{~d}$ for 'Penn A-4' (Fig. 4B). At $16 \mathrm{~d}$ of treatment at $31^{\circ} \mathrm{C}$, 'Putter' had a lower CAT activity than 'PennA-4'(Fig. 4A). The decline of CAT activity for 'Penn A-4' occurred at higher temperatures and later during the treatment than 'Putter'. CAT activity for 'Penn A-4' was higher than 'Putter' at $16 \mathrm{~d}$ of 27 and $31^{\circ} \mathrm{C}$ (Fig. 4A). The difference also occurred at $23 \mathrm{~d}$ at 27,31 , and 35 ${ }^{\circ} \mathrm{C}$ (Fig. 4B), and $43 \mathrm{~d}$ at $25^{\circ} \mathrm{C}$ and higher levels of temperatures (Fig. 4D).

LIPID PEROXIDATION. No cultivar differences in MDAcontent were detected under any temperature regime at $16 \mathrm{~d}$ (Fig. 5A) and $23 \mathrm{~d}$ (Fig. 5B). At $33 \mathrm{~d}$, 'Putter' had a significantly higher MDA content than 'Penn A-4' at 25 and 27 ${ }^{\circ} \mathrm{C}$ (Fig. 5C). At $43 \mathrm{~d}$, MDA content in 'Putter' was significantly higher than that in 'Penn A-4' at $27^{\circ} \mathrm{C}$ and higher temperatures

MDA content was higher at higher root-zone temperature than at lower temperature for both cultivars (Fig. 5). Increases in MDA content occurred at $43 \mathrm{~d}$ at $27^{\circ} \mathrm{C}$ for 'Putter' and $35^{\circ} \mathrm{C}$ for 'Penn A-4'.

Fig. 4. Responses of shoot catalase (CAT) activity of 'Penn A-4' (heat tolerant) and 'Putter' (heat susceptible) creeping bentgrasses to high soil temperatures. Vertical bars at the top of the graphs indicate LSD values $(p=0.05)$ for cultivar comparisons within a given soil temperature treatment. Vertical bars on the right indicate LSD values $(p=0.05)$ for comparisons of different soil temperature treatments within a given cultivar: (A) $16 \mathrm{~d}$ after treatment; (B) $23 \mathrm{~d}$ after treatment; (C) $33 \mathrm{~d}$ after treatment; (D) $43 \mathrm{~d}$ after treatment.
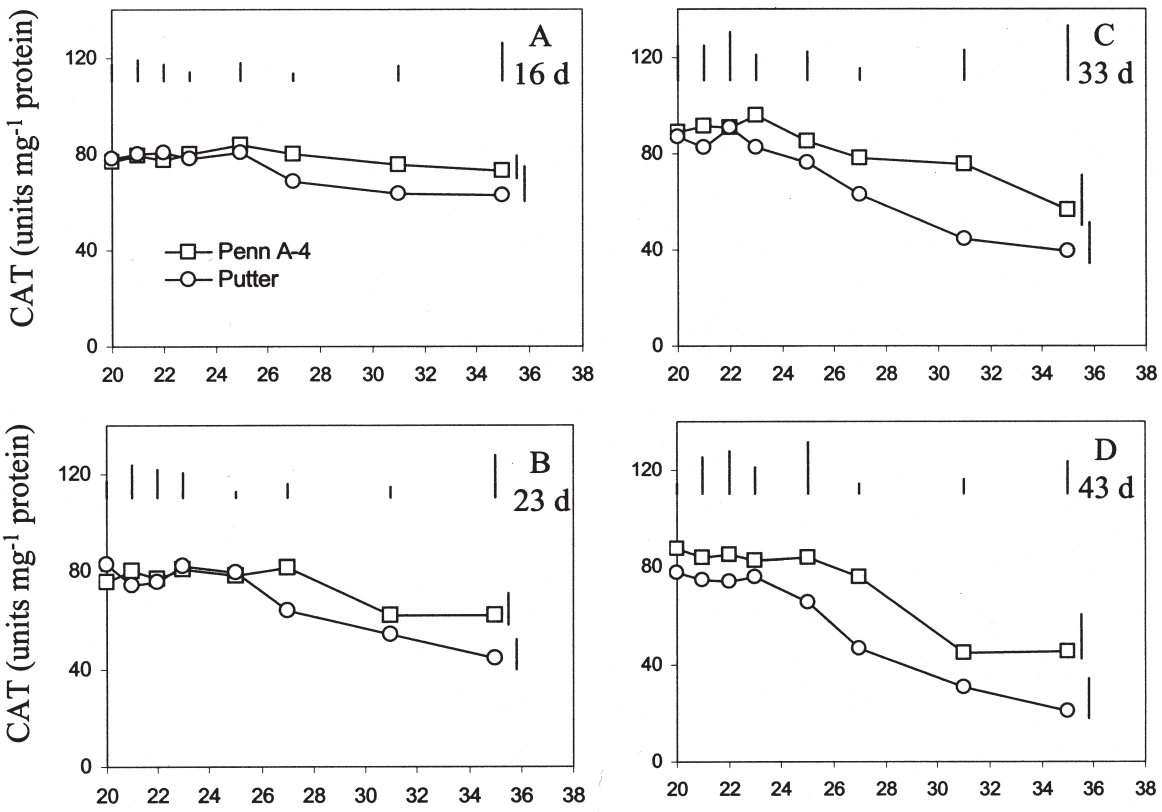

Root-zone temperature $\left({ }^{\circ} \mathrm{C}\right)$

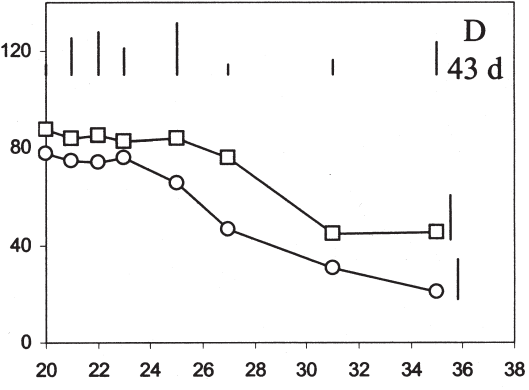

Root-zone temperature $\left({ }^{\circ} \mathrm{C}\right)$ 

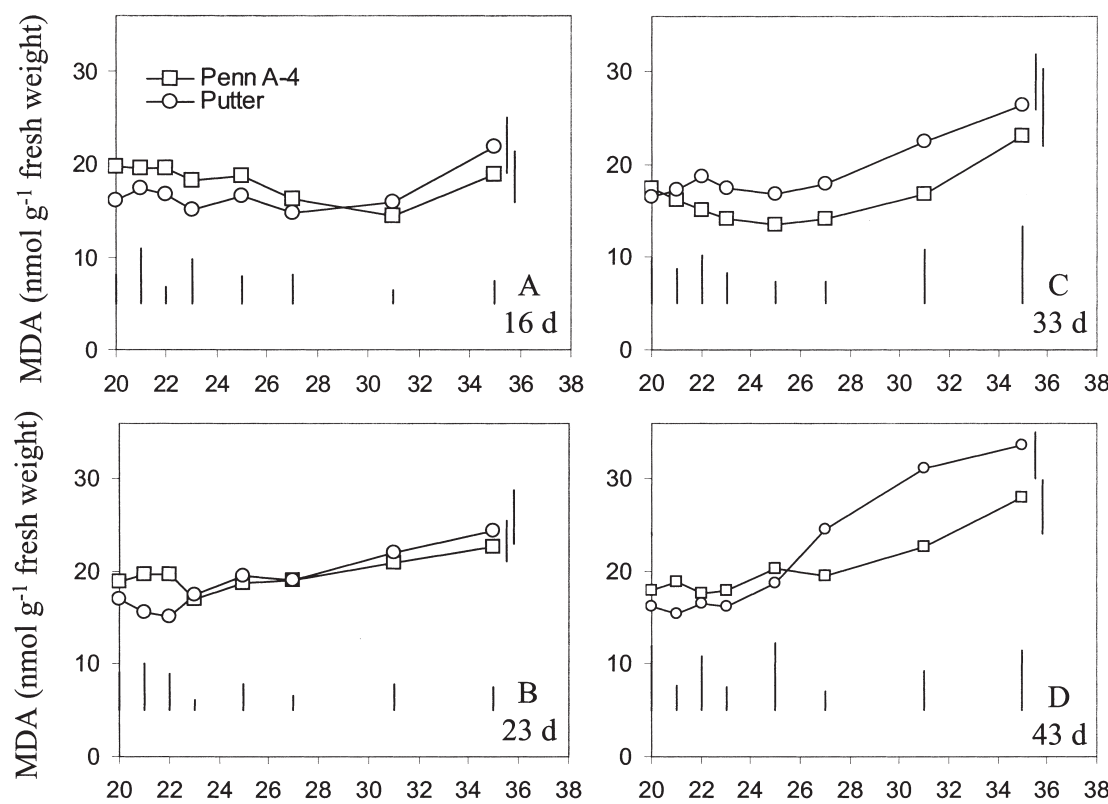

Root-zone temperature $\left({ }^{\circ} \mathrm{C}\right)$

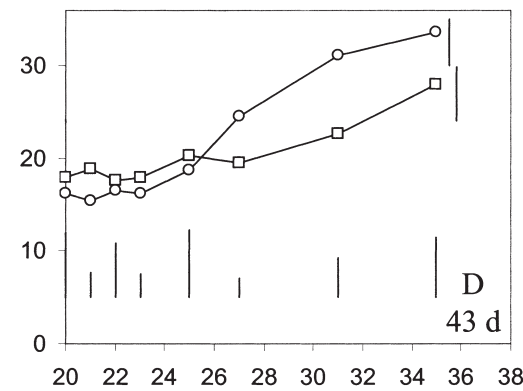

Root-zone temperature $\left({ }^{\circ} \mathrm{C}\right)$

under $25^{\circ} \mathrm{C}$ by the end of this experiment $(47 \mathrm{~d}$ ) (Fig. 9D).

\section{Discussion}

High temperatures are known to induce oxidative injury in plants by inhibiting the antioxidant protection system (Burke and Oliver, 1992; Foyer et al., 1994; Gong et al., 1997; Jagtap and Bhargava, 1995). Liu and Huang (2000) reported the suppression of activity of antioxidant enzymes and the induction of lipid peroxidation when both shoots and roots of creeping bentgrass were exposed to heat stress $\left(35^{\circ} \mathrm{C}\right)$ in creeping bentgrass. However, limited information is available on how increasing only root-zone temperature influences the antioxidant protection system in shoots, even though root-zone temperature is found to be more critical than air temperature in the regulation of plant growth (Kuroyanagi and Paulsen, 1988; Xu and Huang, 2000a, 2000b, 2001). In the present study, the activity of SOD and CAT enzymes for both cultivars decreased at higher root-zone tem-

Fig. 5. Responses of shoot malondialdehyde content of 'Penn A-4' and 'Putter' creeping bentgrasses to high soil temperatures. Vertical bars at the bottom of the graphs indicate LSD values $(p=0.05)$ for cultivar comparisons within a given soil temperature treatment. Vertical bars on the right indicate LSD values $(p=0.05)$ for comparisons of different soil temperature treatments within a given cultivar: (A) $16 \mathrm{~d}$ after treatment; (B) $23 \mathrm{~d}$ after treatment; (C) $33 \mathrm{~d}$ after treatment; (D) $43 \mathrm{~d}$ after treatment.

Cytokinins. Z/ZR content of 'Putter' declined at increased root-zone temperatures; the decline occurred at $20 \mathrm{~d}$ at $27^{\circ} \mathrm{C}($ Fig. $6 \mathrm{~A}$ ) and $37 \mathrm{~d}$ at $25^{\circ} \mathrm{C}$ (Fig. 6C). The decline of Z/ZR content in 'Penn A-4' at the $27^{\circ} \mathrm{C}$ root-zone temperature was found at 37 d of treatment (Fig. 6C). 'Penn A-4' had a higher Z/ZR content than 'Putter' at 37 (Fig. 6C) and 47 d (Fig. 6D) at temperatures between 25 and $35^{\circ} \mathrm{C}$.

The decline of iPA content for 'Putter' started at $20 \mathrm{~d}$ at 27 ${ }^{\circ} \mathrm{C}$ (Fig. 7A) and $37 \mathrm{~d}$ at $25^{\circ} \mathrm{C}$ (Fig. 7C). For 'Penn A-4', no iPA decline was observed at $20 \mathrm{~d}$ at any temperature. The decrease in iPA content at $27^{\circ} \mathrm{C}$ for 'Penn A-4' was noted at $37 \mathrm{~d}$ (Fig. 7C). 'Penn A-4' had a higher iPA content than 'Putter' at all temperatures at or above $27^{\circ} \mathrm{C}$ at 37 and $47 \mathrm{~d}$ of treatment (Fig. 7C and D).

The DHZ/DHZR content of both cultivars did not change for plants maintained at different rootzone temperatures within the first $20 \mathrm{~d}$ of treatment (Fig. 8A). For 'Putter', the decrease in DHZ/DHZR content at a $25{ }^{\circ} \mathrm{C}$ root-zone temperature started at $47 \mathrm{~d}$ (Fig. 8D), and it occurred at $27^{\circ} \mathrm{C}$ at $37 \mathrm{~d}$ of treatment (Fig. 8C). For 'Penn A-4', the decrease in DHZ/DHZR content was only observed at $27^{\circ} \mathrm{C}$ and higher temperatures at 37 and $47 \mathrm{~d}$ (Fig. 8C, D); no decrease in DHZ/DHZR content was observed for $25^{\circ} \mathrm{C}$ and lower temperatures even at $47 \mathrm{~d}$. The decrease of DHZ/DHZR content with higher root-zone temperatures was greater for 'Putter' than for 'Penn A-4' at $37 \mathrm{~d}$ of treatment (Fig. 8C).

The decline of total cytokinin content at $25^{\circ} \mathrm{C}$ for 'Putter' started at $37 \mathrm{~d}$ (Fig. 9C). For 'Penn A-4', the decline of total cytokinin content at $27^{\circ} \mathrm{C}$ started at 37 d (Fig. 9C). However, total cytokinin content in 'Penn A-4' did not show a decline at root-zone temperatures peratures, even though shoots were maintained at the optimal air temperature. Our results suggested that heating roots alone decreased SOD and CAT activity, which could cause accumulation of free radical species and severe oxidative damage in shoots. MDA is a final product of peroxidation of unsaturated fatty acids in phospholipids, and it often is used as a measure of level of lipid peroxidation (Gutteridge and Halliwell, 1990). MDA content of leaves increased at higher root-zone temperatures, and this was accompanied by a decline in antioxidant enzyme activities (Figs. 3,4 , and 5).

Fig. 6. Responses of shoot zeatin and zeatin riboside content of 'Penn A-4' and 'Putter' creeping bentgrasses to high soil temperatures. Vertical bars at the top of the graphs indicate LSD values $(p=0.05)$ for cultivar comparisons within a given soil temperature treatment. Vertical bars on the right indicate LSD values ( $p=0.05)$ for comparisons of different soil temperature treatments within a given cultivar: (A) $20 \mathrm{~d}$ after treatment; (B) $30 \mathrm{~d}$ after treatment; (C) $37 \mathrm{~d}$ after treatment; (D) $47 \mathrm{~d}$ after treatment.
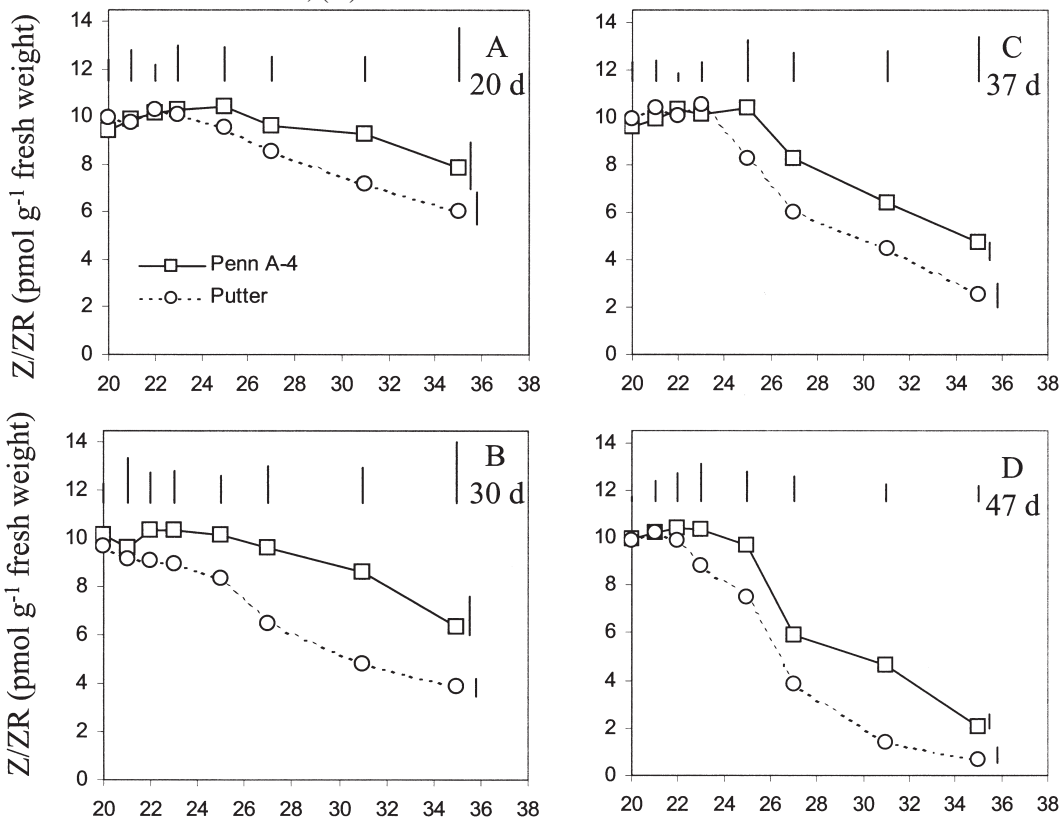

Root-zone temperature $\left({ }^{\circ} \mathrm{C}\right)$

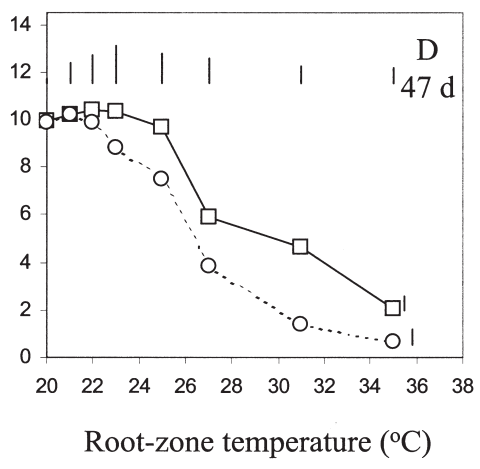



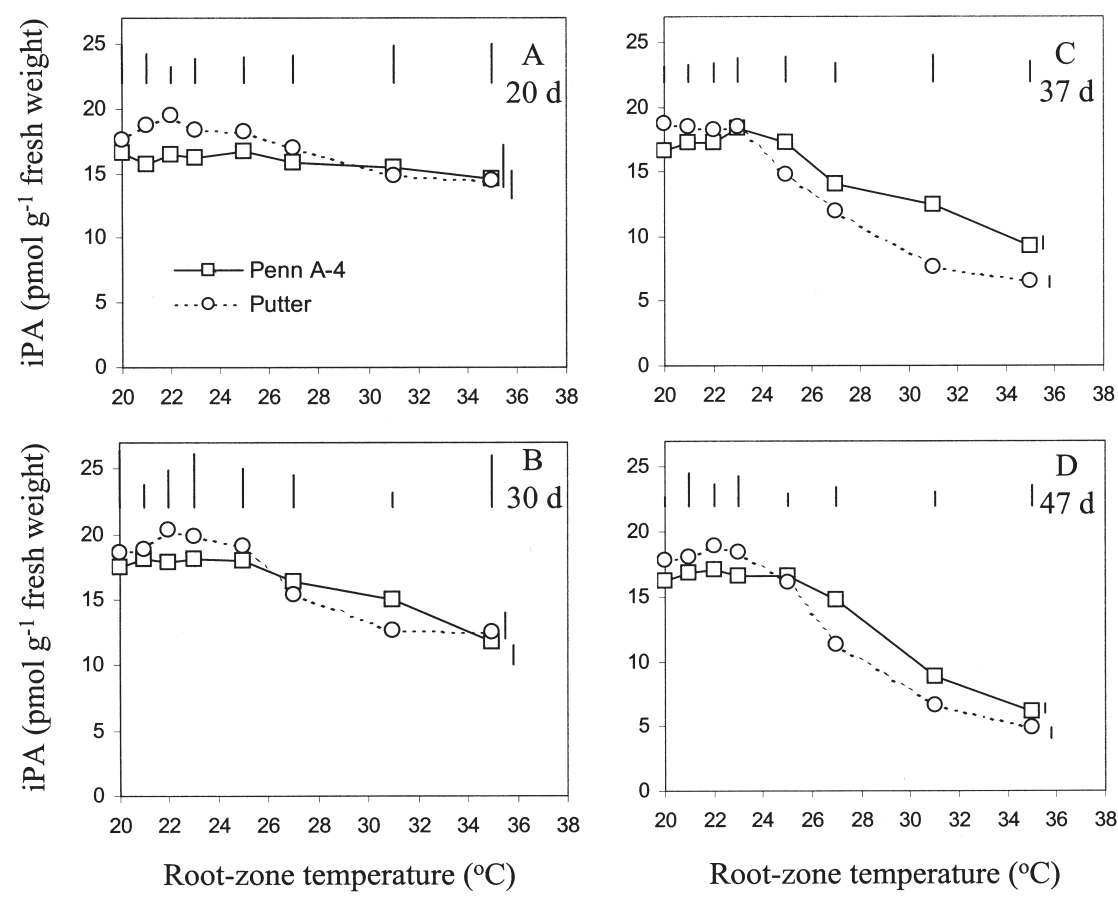

Fig. 7. Responses of shoot isopentenyl adenosine content of 'Penn A-4' and 'Putter' creeping bentgrasses to high soil temperatures. Vertical bars at the top of the graphs indicate LSD values $(p=0.05)$ for cultivar comparisons within a given soil temperature treatment. Vertical bars on the right indicate LSD values $(p=0.05)$ for comparisons of different soil temperature treatments within a given cultivar: (A) $20 \mathrm{~d}$ after treatment; (B) $30 \mathrm{~d}$ after treatment; (C) $37 \mathrm{~d}$ after treatment; (D) $47 \mathrm{~d}$ after treatment.

The effects of root-zone temperature on antioxidant activities and lipid peroxidation varied with the level and duration of the stress, and with cultivars differing in heat tolerance. SOD activity decreased at $25^{\circ} \mathrm{C}$ at $33 \mathrm{~d}$ for 'Putter' (Fig. 3C) and at $27{ }^{\circ} \mathrm{C}$ at $43 \mathrm{~d}$ for 'Penn A-4' (Fig. 3D). The decrease in CAT activity was observed at $27{ }^{\circ} \mathrm{C}$ after $23 \mathrm{~d}$ for 'Putter' and $31{ }^{\circ} \mathrm{C}$ at $23 \mathrm{~d}$ for 'Penn A-4' (Fig. 4B). For MDA, the increase started when roots were exposed to $27^{\circ} \mathrm{C}$ for $43 \mathrm{~d}$ for 'Putter', and to $31{ }^{\circ} \mathrm{C}$ for $43 \mathrm{~d}$ for 'Penn A-4' (Fig. 5D). The changes in both SOD and CAT activities occurred at a lower temperature or earlier during the treatment than MDA, suggesting that the decline in activity of both enzymes led to lipid peroxidation. The cultivar differences in the responses of SOD, CAT, and MDA to higher root-zone temperatures indicate that maintenance of antioxidant activities at low levels of lipid peroxidation were related to an increased tolerance of creeping bentgrass to high root-zone temperatures.

Under prolonged heat stress conditions, leaf senescence is often accompanied by decline of endogenous cytokinin content in leaves (Cheikh and Jones, 1994). Liu et al. (2002) reported that cytokinin content in both leaves and roots decreased when both roots and shoots of creeping bentgrass were exposed to heat stress $\left(35^{\circ} \mathrm{C}\right)$. However, the critical root-zone temperature inducing cytokinin decline in cool-season grasses has not been reported. The root-zone temperature range that

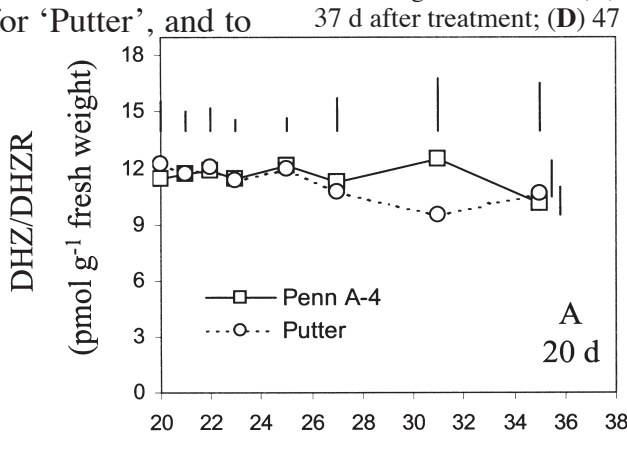
content and antioxidant assays were analyzed at different sampling times due to the limited amount of leaf samples.

Both cytokinin content and antioxidant enzyme activities were affected at lower root-zone temperatures and earlier during the treatment than turf quality in both cultivars. Turf quality started to decline at $31^{\circ} \mathrm{C}$ at $26 \mathrm{~d}$ for 'Putter' and at $35^{\circ} \mathrm{C}$ after $40 \mathrm{~d}$ for 'Penn A-4' (Fig. 2). Huang and Gao (2000) reported the decline in turf quality of 'L-93', 'Crenshaw' and 'Penncross' started when both air and soil temperatures increased to $30^{\circ} \mathrm{C}$ for $20 \mathrm{~d}$.

Fig. 8. Responses of shoot dihydrozeatin and dihydrozeatin riboside content of 'Penn A-4' and 'Putter' creeping bentgrasses to high soil temperatures. Vertical bars at the top of the graphs indicate LSD values $(p=0.05)$ for cultivar comparisons within a given soil temperature treatment. Vertical bars on the right indicate LSD values $(p=0.05)$ for comparisons of different soil temperature treatments within a given cultivar: (A) $20 \mathrm{~d}$ after treatment; (B) $30 \mathrm{~d}$ after treatment; (C) $37 \mathrm{~d}$ after treatment; (D) $47 \mathrm{~d}$ after treatment.
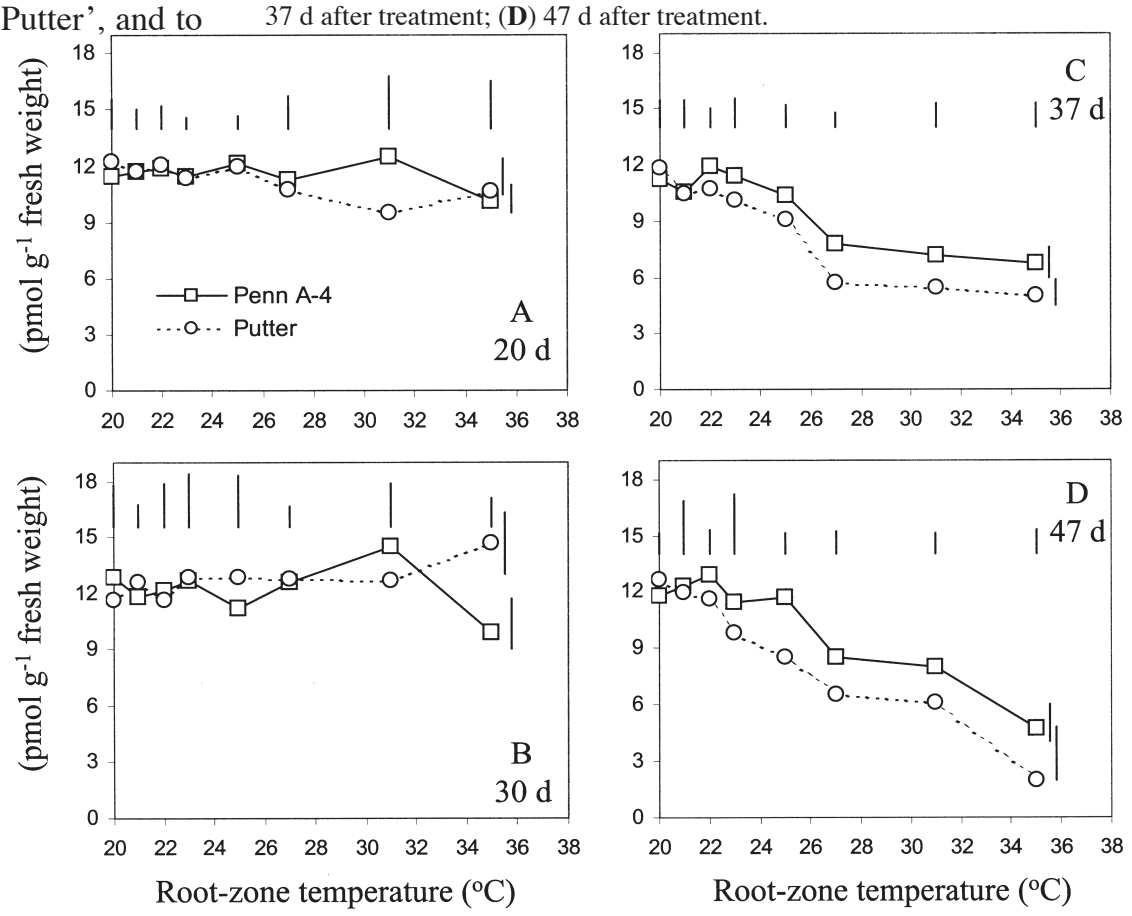

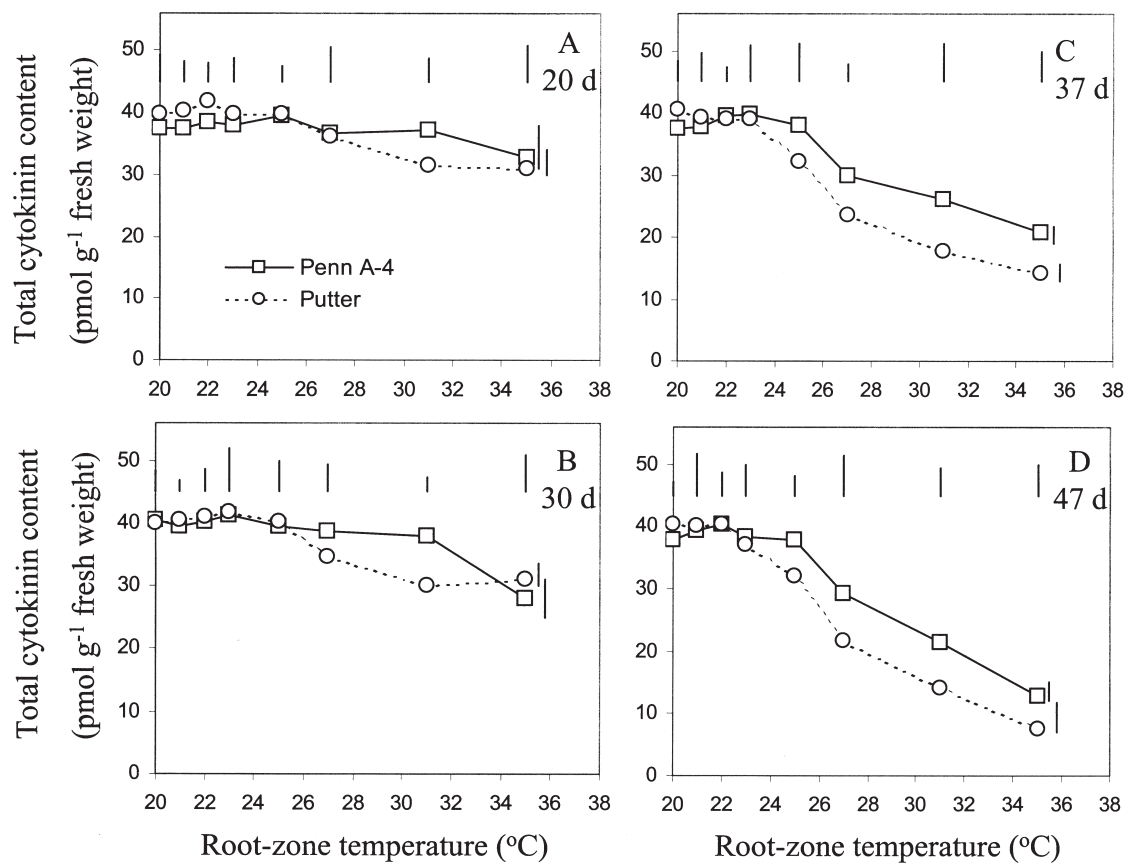

drozeatinriboside. Plant Physiol. 81:516-521.

Foyer, C.H., P. Descourvieres, and K.J. Kunert. 1994. Photoxidative stress in plants. Physiol. Plant. 92: 696-717.

Gan S.S. and R.M. Amasino. 1995. Inhibition of leaf senescence by autoregulated production of cytokinin. Science 270:1986-1988.

Giannopolitis, C.N. and S.K. Ries. 1977. Superoxide dismutase. I. Occurrence in higher plants. Plant Physiol. 59:309-314.

Gong, M., S.N. Chen, Y.Q. Song, and Z.G. Li. 1997. Effect of calcium and calmodulin on intrinsic heat tolerance in relation to antioxidant systems in maize seedlings. Austral. J. Plant Physiol. 24:371-379.

Gunse, B. and F. Eldtner. 1993. Formation of activated states of indoleacetic acid and cytokinins: An experimental approach to a hypothesis concerning signal transduction. J. Plant Physiol. 140:536-540.

Gutteridge, J.M.C. and B. Halliwell. 1990. The measurement and mechanism of lipid peroxidation in biological systems. Trends Biochem. Sci. 15:129-135.

Heath, R.L. and L. Packer. 1968. Photoperoxidation in isolated chloroplasts. I. Kinetics and stoichiometry of fatty acid peroxidation. Arch. Biochem. Biophys. 125:189-198.

Fig. 9 Responses of total cytokinin content of 'Penn A-4' and 'Putter' creeping bentgrasses to high soil temperatures. Vertical bars at the top of the graphs indicate LSD values $(p=0.05)$ for cultivar comparisons within a given soil temperature treatment. Vertical bars on the right indicate LSD values $(p=0.05)$ for comparisons of different soil temperature treatments within a given cultivar: (A) $20 \mathrm{~d}$ after treatment; (B) $30 \mathrm{~d}$ after treatment; (C) $37 \mathrm{~d}$ after treatment; (D) $47 \mathrm{~d}$ after treatment.

These results suggest that shoot injury induced by high root-zone temperatures was associated with the inhibition of cytokinin production and the induction of oxidative stress. Both physiological parameters could be used as an early warning signal of heat injury in creeping bentgrass.

\section{Literature Cited}

Beard, J.B. 1973. Turfgrass: Science and culture. Prentice-Hall, Englewood Cliffs, N.J.

Binns, A.N. 1994. Cytokinin accumulation and action: biochemical, genetic and molecular approaches. Annu. Rev. Plant Physiol. Plant Mol. Biol. 45:173-196.

Bowler, C., M. Van Montagu, and D. Inze. 1992. Superoxide dismutase and stress tolerance. Annu. Rev. Plant Physiol. Plant Mol. Biol. 43: 83-116.

Burke, J.J. and M.J. Oliver. 1992. Differential temperature sensitivity of pea superoxide dismutases. Plant Physiol. 100:1595-1598.

Caers, M., P. Rudelsheim, H. Onckelen, and S. Van. Horemans. 1985. Effect of heat stress on photosynthetic activity and chloroplast ultrastructure in correlation with endogenous cytokinin concentration in maize seedlings. Plant Cell Physiol. 26:47-52.

Carrow, R.N. 1996. Summer decline of bentgrass greens. Golf Course Mgt. 64:51-56.

Chance, B. and A.C. Maehly. 1955. Assay of catalase and peroxidase. Meth. Enzymol. 2:764-775.

Cheikh, N. and R.J. Jones. 1994. Disruption of maize kernel growth and development by heat stress. Role of cytokinin/abscisic acid balance. Plant Physiol. 106:45-51.

Dhindsa, R.S., P.P. Dhindsa, and T.A. Thorpe. 1981. Leaf senescence: correlation with increased levels of membrane permeability and lipid peroxidation, and decreased levels of superoxide dismutase and catalase. J. Expt. Bot. 32:93-101.

Eberle J., A. Arnscheidt, D. Klix, and E.W. Weiler. 1986. Monoclonal antibodies to plant growth regulators. III. Zeatinriboside and dihy-

Hoagland, D.R. and D.I. Arnon. 1950. The water-culture method for growing plants without soil. Calif. Agr. Expt. Sta. Circ. 347.

Huang B. and H. Gao. 2000. Growth and carbohydrate metabolism of creeping bentgrass cultivars in response to increasing temperatures. Crop Sci. 40:1115-1120.

Huang B. and Q. Xu. 2000. Root growth and nutrient element status of creeping bentgrass cultivars differing in heat tolerance as influenced by supraoptimal shoot and root temperatures. J. Plant Nutr. 23: 979-990.

Itai, C., A. Ben-Zioni, and L. Ordin. 1973. Correlative changes in endogenous hormone levels and shoot growth induced by short heat treatments to the root. Physiol. Plant. 29:355-360.

Jagtap, V. and S. Bhargava. 1995. Variation in the antioxidant metabolism of drought tolerant and drought susceptible varieties of Sorghum bicolor (L.) Moench. exposed to high light, low water and high temperature stress. J. Plant Physiol. 145:195-197.

Kuroyanagi, T. and G.M. Paulsen. 1988. Mediation of high-temperature injury by roots and shoots during reproductive growth of wheat. Plant Cell Environ. 11:517-523.

Leshem, Y.Y. 1984. Interaction of cytokinins with lipid-associated oxy free radicals during senescence: a prospective mode of cytokinin action. Can. J. Bot. 62:2943-2949.

Leshem, Y.Y. 1988. Plant senescence processes and free radicals. Free Rad. Biol. Med. 5:39-49.

Liu, X. and B. Huang. 2000. Heat stress injury in relation to membrane lipid peroxidation in creeping bentgrass. Crop Sci. 40:503-510.

Liu, X. and B. Huang. 2002. Cytokinin effects on creeping bentgrass response to heat stress: II. Leaf senescence and antioxidant metabolism. Crop Sci. 42:466-472.

Liu, X., B. Huang, and G. Banowetz. 2002. Cytokinin effects on creeping bentgrass responses to heat stress: I. Shoot and root growth. Crop Sci. 42:457-465.

MacDonald E.M.S. and R.O. Morris. 1985. Isolation of cytokinins by immunoaffinity chromatography and analysis by high-performance liquid chromatography radioimmunoassay. Meth. Enzymol. 110:347-358.

Musgrave, M.E. 1994. Cytokinins and oxidative processes, p. 167-179. In: D.W.S. Mok, and M.C. Mok (eds.). Cytokinins, chemistry, activity, and function. CRC Press, Boca Raton, Fla.

Paulsen, G.M. 1994. High temperature responses of crop plants, p. 365-389. In: K.J. Boote, J.M. Bennett, T.R. Sinclair, G.M.Paulsen(eds.). Physiology and determination of crop yield. ASA-CSSA-SSSA, Madison, Wis.

Pengelly W.L. 1986. Validation of immunoassays, p. 35-43. In: M. Bopp (ed.). Plant growth substances 1985. Springer-Verlag, Berlin. 
Petit-Paly, G., T. Franck, L. Brisson, C. Kevers, J.C. Chenieux, and M. Rideau. 1999. Cytokinin modulates catalase activity and coumarin accumulation in in vitro cultures of tobacco. J. Plant Physiol. 155:9-15.

Price A.H. and G.A.F. Hendry. 1989. Stress and the role of activated oxygen scavengers and protective enzymes in plants subjected to drought. Biochem. Soc. Trans. 17: 493-494.

Ruter, J.M. and D.L. Ingram. 1990. Carbon-labeled photosynthate partitioning in Ilex crenata 'Rotundifolia' at supraoptimal root-zone temperatures. J. Amer. Soc. Hort. Sci. 115:1008-1013.

Ruter, J.M. and D.L. Ingram. 1992. High root-zone temperatures influence RuBisCO activity and pigment accumulation in leaves of 'Rotundifolia' holly. J. Amer. Soc. Hort. Sci. 117:154-157.

Setter T.L., B.A. Flannigan, and J. Melkonian. 2001. Loss of kernel set due to water deficit and shade in maize: Carbohydrate supplies, abscisic acid, and cytokinins. Crop Sci. 41:1530-1540.

Smirnoff, N. 1993. The role of active oxygen in the response of plants to water deficit and desiccation. New Phytol. 125:27-58.

Udomprasert, N., P.H. Li, D.W. Davis, and A.H. Markhart. 1995. III. Root cytokinin level in relation to heat tolerance of Phaseolus acutifolius and Phaseolus vulgaris. Crop Sci. 35:486-490.

USGA/GCSAA/NTEP. 1998. On-site bentgrass test. Prog. Rpt. No. 02-9.

Wang Z., S. Mambelli, and T.L. Setter. 2002. Abscisic acid catabolism in maize kernels in response to water deficit at early endosperm development. Ann. Bot. 90:623-630.
Xu, Q. and B. Huang. 2000a. Growth and physiological responses of creeping bentgrass to changes in air and soil temperatures. Crop Sci. 40:1363-1368.

Xu, Q. and B. Huang. 2000b. Effects of differential air and soil temperature on carbohydrate metabolism in creeping bentgrass. Crop Sci. 40:1368-1374.

Xu, Q. and B. Huang. 2001. Lowering soil temperatures improves creeping bentgrass growth under heat stress. Crop Sci. 41:1878-1883.

Xu, Q., B. Huang, and Z. Wang. 2002. Photosynthetic responses of creeping bentgrass to reduced root-zone temperatures at supraoptimal air temperature. J. Amer. Soc. Hort. Sci. 127:754-759.

Zhang, J. and M.B. Kirkham. 1994. Drought-stress-induced changes in activities of superoxide dismutase, catalase, and peroxidase in wheat species. Plant Cell Physiol. 35:785-791.

Zhang J., and M.B. Kirkham. 1996a. Antioxidant responses to drought in sunflower and sorghum seedlings. New Phytol. 132:361-373.

Zhang, J. and M.B. Kirkham. 1996b. Enzymatic responses of the ascorbate-glutathione cycle to drought in sorghum and sunflower plants. Plant Sci. 113:139-147.

Zhang, X. and R.E. Schmidt. 2000. Hormone-containing products impact on antioxidant status of tall fescue and creeping bentgrass subjected to drought. Crop Sci. 40:1344-1349.

Zhou W.J. and M. Leul. 1999. Uniconazole-induced tolerance of rape plants to heat stress in relation to changes in hormonal levels, enzyme activities and lipid peroxidation. Plant Growth Regulat. 27:99-104. 